\title{
Urgences
}

\section{D'après un poème de $D$. G. Jones, Jardins d'octobre}

\section{Camille Fournier}

Numéro 16, mars 1987

D.G. Jones : d'un texte, d'autres

URI : https://id.erudit.org/iderudit/025383ar

DOI : https://doi.org/10.7202/025383ar

Aller au sommaire du numéro

Éditeur(s)

Urgences

ISSN

0226-9554 (imprimé)

1927-3924 (numérique)

Découvrir la revue

Citer ce document

Fournier, C. (1987). D'après un poème de D. G. Jones, Jardins d'octobre.

Urgences, (16), 40-41. https://doi.org/10.7202/025383ar d'utilisation que vous pouvez consulter en ligne.

https://apropos.erudit.org/fr/usagers/politique-dutilisation/ 


\section{Camille Fournier \\ d'après un poème de D.G. Jones JARDINS D'OCTOBRE}

Bruine, brume

Terre d'ombres

Fleurs souillées

\section{Prisme}

de feuilles mortes.

Pierres épanouies

comme ruines du Tassili

dont l'empreinte subsiste

persiste

S'incrustent encore

en moi qui les broie

les stèles

fleurs nouvelles.

Éden ou géhenne,

ville sainte

ou ville folle des

replis de la nuit?

Ni vie ni deuil...

Je les mêle aux

ténèbres de novembre.

Résurgence des runes. 
J'ai fait une nontraduction, comme le préconise Jacques Brault et c'est pourquoi j'aime mieux écrire: Camille Fournier, d'après un poème de D.G. Jones plutôt que traduit par... J'ai aimé mieux parler des ruines du Tassili, récemment découvertes (en 1956), quant à faire état de volumes écrits à partir de la pierre. J'ai préféré ne pas opter pour les tables de pierre! After 10 P.M. sont devenus «les replis de la nuit» et l'inner city s' est métamorphosée en "ville folle». Angkor Vat aurait pu être maintenue, mais j'ai choisi d'y suppléer une «ville sainte». Enfin, les métamorphoses m'ont fait titrer «jardins" (au pluriel) et le tableau, le paysage, le cliché aurait pu être de novembre. 